\title{
FPGS Gene
}

National Cancer Institute

\section{Source}

National Cancer Institute. FPGS Gene. NCI Thesaurus. Code C103940.

This gene plays a role in the metabolism of both folate and polyglutamate. 